\title{
Novel germline APC gene mutation in a large familial adenomatous polyposis kindred displaying variable phenotypes
}

\author{
R J Scott, R van der Luijt, M Spycher, J-L Mary, A Müller, Th Hoppeler, M Haner, \\ Hj Müller, S Martinoli, P-L Brazzola, P Meera Khan
}

\begin{abstract}
The APC gene is mutated in the germline of people from families where there is a predisposition to develop polyposis coli. Many mutations have been described but the relation between their site and the phenotypic expression of the disease remains unclear. The most commonly seen mutation occurs at codon 1309. Many other mutations have been described towards the 5 end of exon 15 of the APC gene but comparatively few have been seen towards the $3^{\prime}$ end. Recent reports have indicated the possibility of a functional boundary with respect to severity and age of onset of disease, which lies towards the $5^{\prime}$ end of the gene. This report describes a large family whose affected members present with a very variable phenotype ranging from an early onset and severe form to a comparatively mild later onset one. The mutation that predisposes to disease in this family is at a previously undescribed site that lies towards the $3^{\prime}$ end of exon 15 of the APC gene, which results in a stop codon. Interestingly, the stop codon is 63 codons downstream of the mutation and therefore may affect the expression of the disease. The addition of this mutation to the growing list of mutations described in the APC gene may provide some insight into the genotype/phenotype relation of the disease thus contributing to the understanding and significance of mutations at specific sites in the APC gene.

(Gut 1995; 36: 731-736)
\end{abstract}

Keywords: familial adenomatous polyposis, APC gene.

Familial adenomatous polyposis coli (FAP), is an autosomally dominantly inherited disease affecting about 1 in 10000 people $^{1}$ and is characterised by the presence of hundreds to thousands of polyps in the colon, which if left untreated would almost certainly develop into adenocarcinoma. In association with colonic polyps other manifestations of the disease can occur such as desmoid tumours, periampullary carcinomas, osteomas, epidermoid cysts, papillary thyroid carcinomas, and dental abnormalities. $^{23}$ An association of these symptoms is often referred to as Gardners' syndrome.

The FAP locus was assigned to chromosome $5 \mathrm{q}$ using cytogenetic studies ${ }^{4}$ and further refined to $5 q 21-22$ by linkage analysis. ${ }^{56}$ Using multilocus analysis, families suffering from Gardners' syndrome have been shown to be linked to the same locus as FAP. ${ }^{7}$ More recently the gene responsible for FAP (APC gene) has been isolated and characterised. ${ }^{8-11}$ Since the isolation of the APC gene many germline mutations have been found that occur in FAP and Gardners' syndrome patients and putative carriers of the disease. ${ }^{12-17}$

Of particular interest is the relation between APC mutations and the disease phenotype. To date, some correlation seems to exist between the site of mutation and disease severity, however, there remain several inconsistencies as unrelated patients carrying the same point mutation present with very different phenotypes. ${ }^{7} 10$ The simplest explanation for this phenomenon is the presence of an additional gene that is able to modify the expression or function, or both of the APC gene not only in the colon but also at other sites. Therefore it seems that the genotype/phenotype relation is much more complex than originally thought and that other factors participate in the severity of expression of the disease. ${ }^{10}$ In a recent report the existence of a phenotypic boundary has been proposed within the APC gene that seems to correlate with certain aspects of the disease. More specifically, mutations occurring $5^{\prime}$ of exon 9 of the APC gene seem not to be associated with congenital hypertrophy of the retinal pigment epithelium (CHRPEs) whereas almost all mutations $3^{\prime}$ of exon 9 are associated with this phenomenon. ${ }^{18}$ Moreover, the existence of an attenuated form of the disease has also been recognised that is associated with mutations $5^{\prime}$ of exon 6 , providing additional evidence that mutations in the first few exons of the APC gene appear to result in milder forms of the disease. 1920

In this report we present a large kindred in which there is variable phenotype that is expressed at considerably different ages, the most severely affected persons being afflicted with symptoms at 7-8 years of age and others who do not present with disease before their fifth decade. Furthermore, colonic disease expression is extremely variable, ranging from few polyps in some persons to thousands in others. An additional feature is the absence of CHRPEs in this family implying that a $3^{\prime}$ boundary may exist with respect to this aspect of the syndrome. Genetic analysis shows that the underlying genetic defect that is associated 

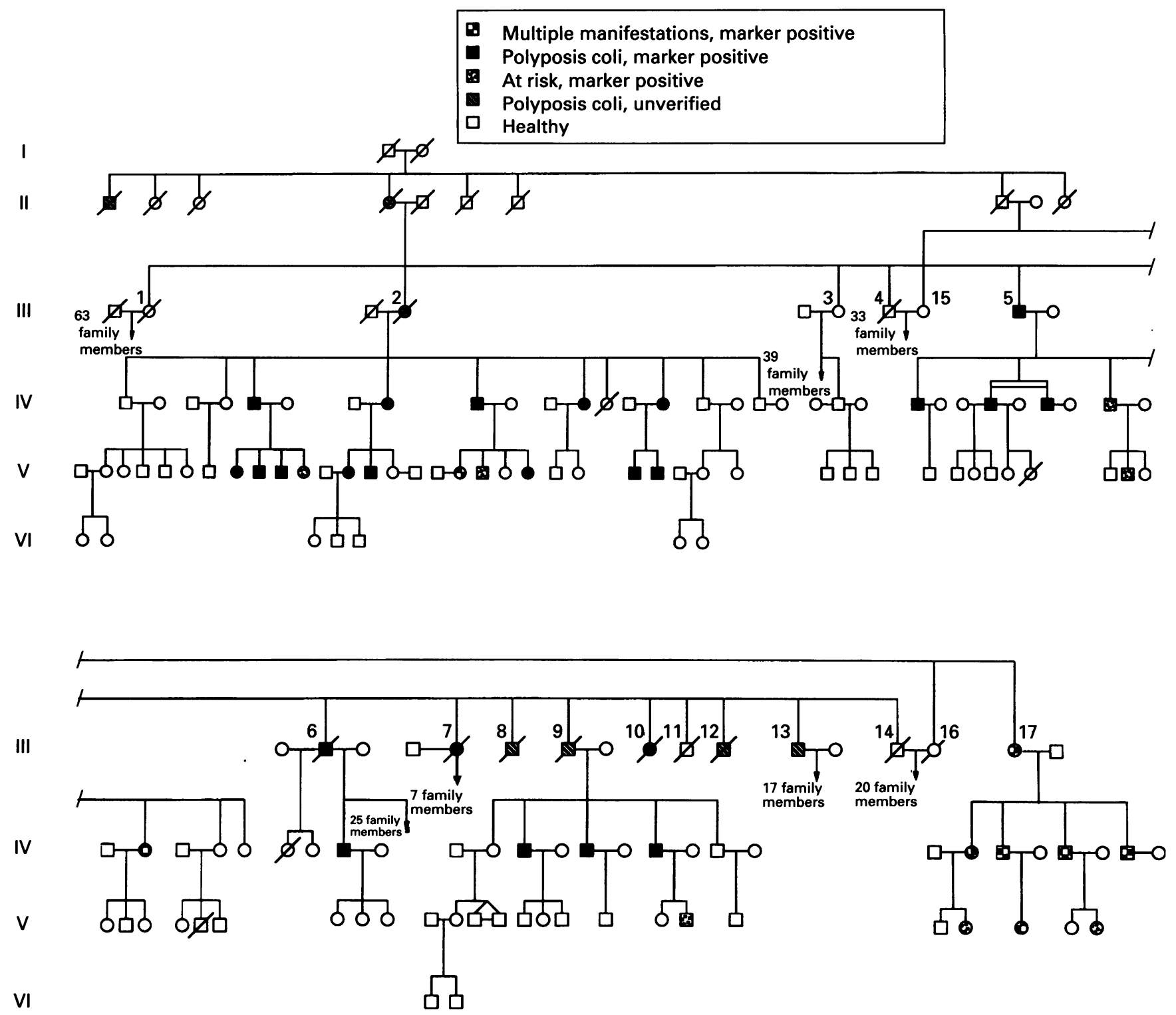

Figure 1: The pedigree showing those subfamilies that were found to contain persons who had inherited the disease allele. The subfamilies are represented from generation III to VI and are numbered between 1 and 17. Descendants from generation III are numbered in accordance to their age and place in their respective family such that, for example, person number 2.1 represents the first child of the third generation in family 2 . Shaded symbols represent persons with only colonic disease and checkered symbols show persons presenting with colonic diseases and extracolonic manifestations of the disease.

with this disorder segregates with a mutation in the APC gene and that it is present in all affected family members.

\section{Methods}

PATIENTS

Figure 1 shows the condensed version of the family pedigree; all subfamilies that are not affected with the disease have been omitted. Dark shaded symbols show persons who have developed colonic disease whereas those who have either developed colonic disease and extracolonic disease or extracolonic disease without colonic disease are shown by checkered symbols. Symptomatic patients were first ascertained at clinical presentation, thereafter relatives were contacted through their family doctor after the index patients had filled out a questionnaire pertaining to FAP in their family. FAP diagnosis was based on colonoscopy whereas Gardners' syndrome patients often presented with other manifestations of the disease before the presence of colonic polyps.

Development of disease in 15 cases was diagnosed over the age of 40 and was frequently restricted to the right side of the colon. Interestingly, polyp density tended to decrease towards lower numbers and the usual florid display of polyps was only seen in a few patients. The Table gives a more detailed breakdown of the phenotype seen in this family. Family members were also assessed for CHRPEs by a qualified and experienced ophthalmologist who was specifically trained to recognise these lesions as it has been suggested that they tend to cosegregate with disease. ${ }^{21}$

\section{DNA isolation}

Genomic DNA was isolated from EDTA blood according to the method described by Miller et al. ${ }^{22}$ Briefly, blood samples were mixed with EL buffer, (155 $\mathrm{mM} \mathrm{NH} \mathrm{NH}_{4} \mathrm{Cl}$, $10 \mathrm{mM} \mathrm{KHCO}, 1 \mathrm{mM}$ EDTA, $\mathrm{pH} \mathrm{7.4)}$ and left on ice for 15 minutes. The lysate was 
Details of the phenotype seen in the family

\begin{tabular}{|c|c|c|c|c|c|}
\hline Patient & Sex & $\begin{array}{l}\text { Age of } \\
\text { onset }\end{array}$ & $\begin{array}{l}\text { DNA } \\
\text { mutation }\end{array}$ & Site & Extracolonic disease \\
\hline \multicolumn{6}{|c|}{ Family 2} \\
\hline 2 & $\mathbf{F}$ & Unknown & ND & Unknown & Unknown \\
\hline 2.3 & $\mathbf{M}$ & 42 & + & Colon & Desmoid ileum \\
\hline 2.3 .1 & $\mathbf{F}$ & Unknown & + & Colon & - \\
\hline 2.3 .2 & $\mathbf{M}$ & Unknown & + & Colon & - \\
\hline 2.3 .3 & $\mathbf{M}$ & Unknown & + & Colon & - \\
\hline 2.3 .4 & $\mathbf{F}$ & & + & Colon & - \\
\hline 2.4 & $\mathbf{F}$ & 42 & + & Colon & - \\
\hline 2.4 .1 & $\mathbf{F}$ & 22 & + & Colon & - \\
\hline 2.4 .2 & $\mathbf{M}$ & 33 & + & Ileocaecal & - \\
\hline 2.5 & $\mathbf{M}$ & 45 & + & $\begin{array}{l}\text { Transverse descending } \\
\text { sigmoid }\end{array}$ & - \\
\hline 2.5 .1 & $\mathrm{~F}$ & 22 & + & $\begin{array}{l}\text { Colon and }>100 \text { polyps in } \\
\text { duodenum and ileum }\end{array}$ & Fibroma \\
\hline 2.5 .4 & $\mathrm{~F}$ & 21 & + & Descending colon & - \\
\hline 2.6 & $\mathbf{F}$ & 42 & + & Colon & - \\
\hline 2.8 & $\mathbf{F}$ & 37 & + & Colon & - \\
\hline 2.8 .1 & $\mathbf{M}$ & 22 & + & Proximal colon & - \\
\hline $\begin{array}{l}2.8 .2 \\
\text { Family }\end{array}$ & $5^{M}$ & 20 & \multicolumn{3}{|c|}{ Family 5} \\
\hline 5 & $\mathbf{M}$ & 70 & + & $\begin{array}{l}\text { Rectum sigmoid } \\
\text { descending colon }\end{array}$ & $\begin{array}{l}\text { Prostate cancer Paget's } \\
\text { disease }\end{array}$ \\
\hline 5.1 & $\mathbf{M}$ & 46 & + & Colon & - \\
\hline 5.2 & $\mathbf{M}$ & 48 & + & Colon & - \\
\hline 5.3 & $\mathbf{M}$ & 50 & + & Colon & - \\
\hline 5.4 & $\mathbf{M}$ & & + & No symptoms & - \\
\hline \multicolumn{6}{|c|}{ Family 6} \\
\hline 6 & $\mathbf{M}$ & 63 & ND & Unknown & $\begin{array}{l}\text { Adenocarcinoma of the } \\
\text { stomach with liver } \\
\text { metastases }\end{array}$ \\
\hline 6.2 & $\mathbf{M}$ & 31 & + & Colon & - \\
\hline $\begin{array}{l}6.4 \\
\text { Family }\end{array}$ & $7^{M}$ & & + & Colon & - \\
\hline & $F$ & 68 & ND & Colon & Unknown \\
\hline 9 & \multicolumn{5}{|c|}{ Family 9} \\
\hline 9.2 & $\mathbf{M}$ & 47 & & Colon & - \\
\hline 9.3 & $\mathbf{M}$ & 43 & + & Colon & - \\
\hline 9.4 & $\mathbf{M}$ & 38 & & Colon & - \\
\hline 9.4 .2 & $\mathbf{M}$ & 4 & ND & - & $\begin{array}{l}\text { Malformation of brain and } \\
\text { vitium cordis }\end{array}$ \\
\hline \multicolumn{6}{|c|}{ Family 10} \\
\hline Family & 13 & 50 & ND & Colon & Unknown \\
\hline $\begin{array}{l}13 \\
\text { Family }\end{array}$ & $\underset{17}{M}$ & Unknown & + & Colon & Unknown \\
\hline 17 & $\mathbf{F}$ & 65 & + & Colon & Desmoid \\
\hline 17.1 & $\mathbf{F}$ & 39 & + & Trans sigmoid & Desmoid \\
\hline 17.1.1 & $\mathbf{M}$ & 20 & + & No symptoms & - \\
\hline 17.1.2 & $\mathrm{F}$ & & + & No symptoms & - \\
\hline 17.2 & $\mathbf{M}$ & 38 & + & Colon & Gastric polyps and cysts \\
\hline 17.2.1 & $\mathbf{F}$ & 8 & + & - & $\begin{array}{l}\text { Exostose osteoma of the } \\
\text { mandible }\end{array}$ \\
\hline 17.3 & $\mathbf{M}$ & & + & Colon & Fundus and body of stomach \\
\hline 17.3 .1 & $\mathbf{F}$ & & + & No symptoms & - \\
\hline 17.3 .2 & $\mathrm{~F}$ & & + & No symptoms & - \\
\hline 17.4 & $\mathbf{M}$ & 24 & + & Left colon & $\begin{array}{l}\text { Gastric body and fundus } \\
\text { micropolyps }\end{array}$ \\
\hline
\end{tabular}

Mean age of onset 39 years; 43 cases; 23 male, 20 female. Only subfamilies that contain affected persons have been represented. $\mathrm{ND}=$ not determined, unknown $=$ medically unverifiable, $+=$ positive genetic result, $-=$ no extracolonic disease to date. DNA mutation +ve implies that these persons carried a mutation in exon $15 n$ of the APC gene. Site refers to disease seen within the colon and whether all of the colon is affected or only specific areas within it. All other subfamilies are clinically and genetically negative and therefore not represented.

centrifuged, washed twice with EL buffer, and the intact lymphocyte pellet resuspended in NL buffer (10 mM TRIS-Cl, pH 8.2, $400 \mathrm{mM}$ $\mathrm{NaCl}, 2 \mathrm{mM} \mathrm{Na} \mathrm{m}_{2}$ EDTA, $1 \%$ SDS, and 200 $\mu \mathrm{g} / \mathrm{ml}$ proteinase $\mathrm{K}$ ), and incubated overnight at $37^{\circ} \mathrm{C}$. The next day, $1 \mathrm{ml}$ of $6 \mathrm{M} \mathrm{NaCl}$ was added and vigorously shaken followed by centrifugation to remove cellular proteins. The supernatant containing the DNA was placed in a fresh tube and the DNA precipitated with ethanol. The resulting DNA pellet was washed with $70 \%$ ethanol, dried briefly, and then resuspended in $1 \mathrm{ml}$ of TE buffer (10 mM TRIS-Cl, pH 7.5, 0.1 M EDTA).

\section{DNA amplification}

Single strand conformation analysis polymerase chain reaction (PCR) was performed using primer pairs previously described. ${ }^{8}$ Denaturing gradient gel electrophoresis PCR was similar to single strand conformation analysis PCR but the oligonucleotides used for the analysis included a GC clamp. ${ }^{12}$ DNA samples were amplified using PCR (5 min $93^{\circ} \mathrm{C}$, once, $70^{\circ} \mathrm{C}$ for a 'hot start') Taq I polymerase (for as long as required), $30 \mathrm{~s}$ at $93^{\circ} \mathrm{C}, 30 \mathrm{~s}$ at $55^{\circ} \mathrm{C}, 60 \mathrm{~s}$ at $72^{\circ} \mathrm{C}, 19$ times; and finally, $5 \mathrm{~min}$ at $72^{\circ} \mathrm{C}$ for a final extension using standard conditions in the presence of $0 \cdot 1 \mu \mathrm{l}$ of $3000 \mathrm{Ci}\left[\right.$ alpha- $\left.{ }^{32} \mathrm{P}\right] \mathrm{dCTP} / \mathrm{mmol}$.

\section{Electrophoresis}

Denaturing gradient gel electrophoresis - optimal denaturating gradient gel electrophoresis conditions for the analysis of the exon 13 polymorphism were determined both by perpendicular denaturating gradient gel electrophoresis and computer simulations as described elsewhere. ${ }^{12}$ Parallel denaturating gradient gel electrophoresis was performed as previously described. ${ }^{23}$ The gel consisted of $6 \%$ polyacrylamide containing a linearly increasing gradient of denaturant solution $(100 \%$ denaturant $=7 \mathrm{M}$ urea, and $40 \%$ formamide). Denaturating gradient gel electrophoresis were performed at $60^{\circ} \mathrm{C}$ in TAE buffer.

Single strand conformational polymorphism gel analysis - samples amplified by PCR were diluted 100 -fold in $95 \%$ formamide, $40 \mathrm{mmol}$ EDTA, 0.05\% bromophenol blue, and $0.05 \%$ xylene cyanol, and heated to $80^{\circ} \mathrm{C}$ for two minutes and then applied to a $5 \%$ polyacrylamide gel. Electrophoresis was performed for 8 to 10 hours depending on the size of the APC segment amplified. Conformers were directly sequenced according to standard methods using the Sequenase II kit from USB.

\section{Results}

As this family was so heterogeneous with respect to the expression of FAP a detailed investigation into the presence of CHRPE's was performed. Ophthalmological examination of all affected family members showed an absence of CHRPEs in all but one of the patients. Similarly, all unaffected persons (both at risk and low risk groups) were devoid of CHRPE's showing that this method of screening could not be used in this family to identify persons at risk.

Before screening this family for mutations within the APC gene, linkage analysis was performed to find out if indeed the disease was linked to the APC locus (data not shown). One internal marker (exon 13, polymorphic using denaturating gradient gel electrophoresis analysis but not single strand conformation analysis under the conditions we used) in association with five external markers established beyond doubt that this disease segregated with the APC locus, together the lod score was over $2 \cdot 2$. Thereafter, both single strand conformation and denaturating gradient gel electrophoresis analysis were performed to 


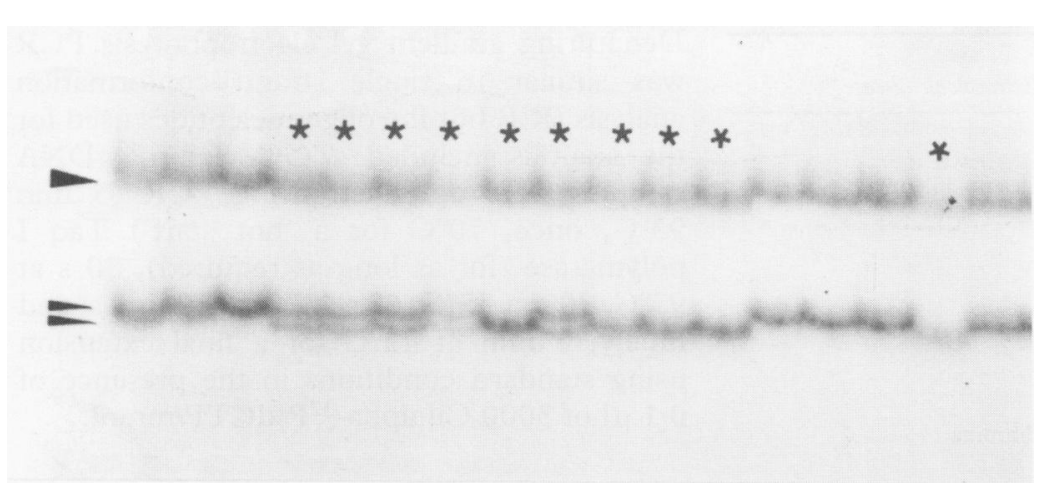

Figure 2: Conformational shift on exon 15n of the APC gene. The large arrow shows the single strand conformation analysis conformer that segregates with the disease. The two small arrows show the polymorphic nature of this region. Persons carrying the mutation are shown by a star above their respective lane.

screen $60 \%$ and $40 \%$ of the entire coding region, respectively. The two different methods were used as several of the corresponding primers for denaturating gradient gel electrophoresis analysis were not available. Using this strategy several polymorphic sites were identified within the APC gene. An uninformative polymorphism was found in exon 6 , which was only present in three subjects (two unaffected and one affected) of 99. No polymorphisms were identified between exons 4 and 12 and in exon 14. Exon 15 was split into 23 sections $(\mathrm{a}-\mathrm{w})$ as previously described. ${ }^{8}$ Within this exon there exist several polymorphisms, at $15 \mathrm{k}$ and $15 \mathrm{j}$. The 15k polymorphism was identified using single strand conformation analysis, which is in linkage disequilibrium with that found in exon 13. In addition, the polymorphism found by single strand conformation analysis in exon $15 \mathrm{k}$ is probably identical to that identified by denaturating gradient gel electrophoresis analysis in exon $15 j$ as the oligonucleotides used for both methods overlap one another.

A conformational shift found in exon 15n (Fig 2 shows an example of some of the single strand conformation analysis for the whole family) was, however, seen in only those members who either had the disease or were (based on linkage analysis) considered to be at very high risk of developing it. In total 35 persons were identified as carrying this mutation of which five have not yet developed any symptoms. There are two apparent shifts but only the conformer indicated by the large arrow is exclusive to the disease. The other conformer appeared in other unaffected persons and represents an additional poorly resolvable polymorphism under the conditions that were

- GAC - CAA - GAA - AAC - AAC - ATA - AAG - AAA - ATG - AAC -

Figure 3: Sequence analysis of exon $15 n$ showed a base pair deletion at position 5934, which was identical in patients who presented with colonic disease alone or extracolonic disease with or without colonic disease. used. As the specific conformational variant cosegregated with the disease in all affected persons displaying considerably different phenotypes, sequence analysis was performed.

The mutation at this site was found to be a deletion of an adenine base at position 5934 (shown in Fig 3 ) causing a frame shift that gives rise to a stop codon 63 codons downstream at codon 2044. The mutation was found to be identical in persons who developed extracolonic or colonic disease. The presence of a stop codon in this region of the APC gene was confirmed by the protein truncation test. ${ }^{24}$ A $2.2 \mathrm{~kb}$ segment of exon 15 , encompassing codons 1595 to 2337, was PCR amplified from genomic DNA and subjected to in vitro coupled transcription and translation in a rabbit reticulocyte lysate system. SDS-PAGE analysis of the translation products from an affected family member showed a truncated peptide of the expected size, in addition to the normal product. Similar analysis in an unaffected subject from the pedigree only showed translation products corresponding to the wild type APC allele (data not shown).

\section{Discussion}

This family illustrates the difficulties that can be met when dealing with a hereditary predisposition that presents itself with a variable phenotype, which makes it difficult in some cases to decide whether it belongs to one predisposition or another. There are several examples of there being site specificity, later age of diagnosis, and mucinous carcinoma, all of which are reminiscent of hereditary non-polyposis colorectal cancer. ${ }^{25}$ It does not, however, meet the Amsterdam criteria, which requires the absence of polyposis even though many members of this family present with only a few polyps. The extracolonic manifestations of the disease, however, distinguish it quite clearly from hereditary non-polyposis colorectal cancer as not only were desmoids evident in a significant number of patients but also other typical signs of FAP (osteomas and epidermoid cysts, etc) were seen in some family members. Strong support that this family belongs to the entity of FAP coli comes from linkage analysis, which provided a lod score of over $2 \cdot 2$. Although not highly significant (that is, over 3), it does represent significant proof that this disease segregates with the APC gene.

Interestingly, only one person presented with CHRPEs who also did not have a particularly severe form of the disease supporting the notion that there exist families where CHRPEs are not of any predictive value in assessing carrier status. This is interesting as it has been suggested that mutations that occur after exon 9 are associated with the development of CHRPEs. ${ }^{18}$ As the mutation described here represents one that lies in a position where CHRPEs should be expected it may suggest that another 'boundary' exists $5^{\prime}$ of the mutation described here.

To further characterise the underlying genetic mutation that lead to the increased 
susceptibility of colorectal cancer development, an investigation into the APC gene was performed. This showed a unique mutation at position 5934, which leads to a stop codon mutation at codon 2044. The distance from the mutation to the stop codon is unusually long (63 codons) and is the furthest distance away from a mutation that has so far been described for the APC gene. This result was further confirmed by looking at a synthetic protein product showing the approximate size of the mutated protein being smaller than that of the wild type protein (van der Luijt, results not shown), highlighting a continuing feature of APC mutations in that most seem to result to stop codons, ${ }^{17}$ a finding that seems to be unique to this gene.

This result implies that the $\mathrm{C}$ terminal of the protein is important in governing the physiological function of the gene, however, the precise function of the gene remains to be determined. The mutation at position 5934 does not seem to be a useful predictive marker with respect to the severity of the disease. Sequence analysis of DNA from a person suffering from only colonic disease and one who presented with osteomas and desmoids before colonic disease was identical. Such findings have been described before in separate unrelated families but not in one and the same family. As this mutation occurs in several members of the same family and does not correlate with severity of disease other factors need to be considered. Furthermore, the presence of such a long tail of nonsense amino acid sequence after the mutation may also significantly affect the function of the predicted protein complex and could be an explanation for the variable phenotype seen in this family. The simplest explanation, however, is the presence of another gene, which when present in a particular form modifies the expression of the APC gene, such a gene would have to be comparatively polymorphic as it occurs both within and between families. In the present family this is difficult to examine because there is a consanguineous marriage, which may adversely affect variation within one of the branches of the family. There is considerable variation in those branches, however, which are not interrelated, showing that there is variation between and within non-consanguineous branches. It has been reported that the relation between the site of the mutation and the severity of disease is inversely related to the position of the mutation, otherwise referred to as the APC paradox. ${ }^{26}$ This paradox results from a tendency of milder phenotypes to segregate with mutations towards the $5^{\prime}$ end of the gene and the more severe forms of the disease to be associated with the $3^{\prime}$ end. Indeed it has recently been reported that a milder form of the disease otherwise known as the attenuated form of FAP (referred to as AAPC) seems to be associated with mutations that occur before codon $157 . .^{19}$ With respect to the family under consideration here, a mutation that on the one hand seems to give rise to a later onset of disease yet is associated in many cases with a severe phenotype seems difficult to explain in view of the apparent later age of onset seen in AAPC families. As the most probable explanation is the presence of a modifying gene ${ }^{8}$ a possible candidate may well be found in those families that are not linked to the APC gene but present with identical symptoms. ${ }^{27}$

In summary, we have identified an unusual germline mutation in the APC gene that seems to give rise to varying degrees of clinical severity, ranging from a comparatively mild phenotype to a very severe one. The presence of the mutation at a site that is in the last $30 \%$ of the gene that gives rise to such a varied phenotype raises the possibility that functional inactivation can occur even more $3^{\prime}$ than originally thought. ${ }^{28}$ Further analysis of the APC gene product and its interaction with both $\alpha$ catenin and $\beta$ catenin and other cell matrix proteins will resolve the function of this enigmatic protein.

This work is supported by Swiss National Fund Nos 32-300007.90 and 32-32556.91.

1 Bülow S. Familial polyposis coli. Dan Med Bull 1987; 34: $1-15$

2 Gardner EJ. A genetic and clinical study of intestinal polyposis, a predisposing factor for carcinoma of the colon and rectum. Am F Hum Genet 1951; 3: 167-76.

3 Lewis RA, Crowder WE, Eierman LA, Nussbaum RL Ferrel RE. The Gardner syndrome: significance of ocular features. Ophthalmology 1984; 91: 916-25.

4 Herrera L, Kakati S, Gibas L, Pietrzak E, Sandberg AA. Gardner syndrome in a man with an interstitial deletion of 5q. Am $\mathcal{F}$ Med Genet 1986; 25: 473-6.

5 Bodmer WF, Bailey CJ, Bodmer J, Bussey HJR, Ellis A, Gorman P, et al. Localization of the gene for familial adenomatous polyposis on chromosome 5. Nature 1987; 328: 614-6.

6 Leppert M, Dobbs M, Scambler P, O'Connel P, Nakamura $\mathrm{Y}$, Stauffer D, et al. The gene for familial polyposis coli maps to the long arm of chromosome 5. Science 1987; 238: 1411-3.

7 Nakamura Y, Lathrop M, Leppert M, Dobbs M, Wasmuth $\mathrm{J}$, Wolff $\mathrm{E}$, et al. Localization of the genetic defect in familial adenomatous polyposis within a small region of chromosome 5. Am $\mathcal{F}$ Hum Genet 1988; 43: 638-44.

8 Groden J, Thliveris A, Samowitz W, Carlson M, Gelbert L Albertsen $\mathrm{H}$, et al. Identification and characterization of the familial adenomatous polyposis gene. Cell 1991; 66: 589-600.

9 Joslyn G, Carlson M, Thliveris A, Albertsen H, Gelbert L, Samowitz W, et al. Identification of deletion mutations and three new genes at the familial polyposis locus. Cell 1991; 66: 601-13.

10 Nishisho I, Nakamura Y, Miyoshi I, Miki Y, Ando H, Horii A, et al. Mutations of chromosome 5q21 genes in FAP and colorectal cancer patients. Science 1991; 253: 665-9.

11 Kinzler KW, Nilbert MC, Su L-K, Vogelstein B, Bryan T, Levy D, et al. Identification of FAP locus genes from chromosome 5q21. Science 1991; 253: 661-5.

12 Fodde R, Van der Luijt R, Wijnen J, Tops C, Van der Klift $\mathrm{H}$, Van Leeuwen-Cornelisse I, et al. Eight novel inactivating germline mutations at the APC gene identified by denaturing gradient gel electrophoresis. Genomics 1992; 13: 1162-8.

13 Miyoshi Y, Ando H, Nagase H, Nishisho I, Horii A, Miki Y, et al. Germ-line mutations of the APC gene in 53 familial adenomatous polyposis patients. Proc Natl Acad Sci USA 1992; 89: 4452-6.

14 Groden J, Gelbert L, Thliveris A, Nelson L, Robertson M, Joslyn G, et al. Mutational analysis of patients with adenomatous polyposis: identical inactivating mutations in unrelated individuals. Am f Hum Genet 1993; 52: 263-72.

15 unrelated individuals. Am f Hum Genet 1993; 52: 263-72. Grammatico P, Groden J, et al. Identification of APC gene mutations in Italian adenomatous polyposis coli patients by PCR-SSCP analysis. Am f Hum Genet 1993; 52: 280-5

16 Olschwang $\dot{S}$, Kaurent-Puig P, Groden J, White R, Thomas G. Germ-line mutations in the first 14 exons of the adenomatous polyposis coli (APC) gene. Am F Hum Genet 1993; 52: 273-9.

17 Nagase $\mathrm{H}$, Nakamura Y. Mutations of the APC (adenomatous polyposis coli) gene. Hum Mut 1993; 2: 425-34.

18 Olscwang S, Tiret A, Laurent-Puig P, Muleris M, Parc R Thomas G. Restriction of ocular fundus lesions to a specific subgroup of APC mutations in adenomatous polyposis coli patients. Cell 1993; 75: 959-68.

19 Spirio L, Otterud B, Stauffer D, Lynch H, Lynch P, Watson $P$, et al. Linkage of a variant or attenuated form of 
adenomatous polyposis coli to the adenomatous polyposis coli (APC) locus. Am f Hum Genet 1993; 51: 92-100.

20 Spirio L, Olschwang S, Groden J, Robertson M, Samowi W, Joslyn G, et al. Alleles of the APC gene: an attenuated form of familial polyposis. Cell 1993; 75: 951-7.

21 Chapman PD, Church W, Burn J, Gunn A. The detection of congenital hypertrophy of the retinal pigment epithelium (CHRPE) by indirect ophthalmoscopy: a releple clinical feature of familial adenomatous polyposis. BMF 1989; 298: 353-4.

22 Miller SA, Dykes DD, Polesky HF. A simple salting out procedure for extracting DNA from human nucleated cells. Nucleic Acids Res 1988; 16: 739.

Losekoot M, Fodde R, Harteveld CL, Heeren v $\mathrm{H}$ Giordano PC, Bernini LF. Denaturing gel electrophoresi and direct sequencing of PCR amplified genomic DNA: a rapid and reliable diagnostic approach to B-thalassemia. Br F Haematol 1990; 76: 269-74.
24 Van der Luijt R, Meera Khan P, Vasen H, Van Leeuwen C, Tops C, Roest P, et al. Rapid detection of translation-terminating mutations at the adenomatous polyposis coli (APC) gene by direct protein truncation test. Genomics 1994; 20: $1-4$

25 Lynch HT, Watson P, Kriegler M, Lynch JF, Lanspa SJ, Marcus J, et al. Differential diagnosis of hereditary nonpolyposis colorectal cancer (Lynch syndrome I and Lynch syndrome II). Dis Colon Rectum 1988; 31: and Lyn 7 .

26 Foulkes W. Genetics of cancer. Lancet 1992; 340: 1402-3.

27 Stella A, Resta N, Gentile M, Susca F, Mareni C, Montera MP, et al. Exclusion of the APC gene as the cause of a variant form of familial adenomatous polyposis. Am f Hum Genet 1993; 53: 1031-7.

28 Bodmer W, Bishop T, Karran P. Genetic steps in colorecta cancer. Nature Genetics 1994; 6: 217-9. 
The first chapter, which is devoted to 'Hepatitis', contains some very low key statements such as '... the surgeon plays a critical role when medical therapy is no longer possible ...' and 'The clinical immunologist is responsible for performing the many immunologic assays required to identify and characterise the different forms of chronic hepatitis.' This chapter might be satisfactory for undergraduate teaching but is not detailed enough for trainee specialists. In this and in some of the subsequent chapters it was not always clear which readership the editors had in mind when they started the project.

Chapter two, on hepatic failure, is also rather disappointing. A discussion of pathogenesis is confined to just one column and the text includes unhelpful phrases such as 'Transaminases are usually elevated, often dramatically', and 'Thus the transplant team needs to be involved in a timely way for those patients deemed to be candidates'. These comments again suggested that the editors had not defined the level of expertise they expected from their readership and this was again evident in chapter 4 on portal hypertension. In this chapter there is considerable emphasis on the technique and indications for transjugular intrahepatic portosystemic shunt (TIPS) procedures but little on the details of more conventional surgical procedures. There is no analysis of the problems of extrahepatic portal hypertension in which neither TIPS or transplantation are options, and no discussion on the value of devascularisation procedures in the bleeding patient.

The concept of inviting such a large number of contributors was very ambitious but this may have been the cause of some of the inconsistencies. Drug dosages, for example, are detailed in some chapters (hepatic failure), but are completely absent in others (portal hypertension). Surgical techniques are described extensively in some sections (hydatid disease) but are absent in others. Most of the important inconsistencies are found in the first few chapters and if the book was intended for fellow hepatologists then in my opinion the data (and the references) should have been much more complete.

However, the later chapters, especially those concerning pancreatic disease, are very good overviews on management and I particularly liked those on pancreatitis. Therefore despite my reservations I think that the book can be recommended as a useful addition to the library of the trainee gastroenterologist or surgeon.

E R HOWARD

Longitudinal Muscle in Esophageal Disease. By O Arthur Stiennon. (Pp 300; illustrated; \$150.) Maddison, Wisconsin: WRS Press, 1995. ISBN 0-9644 594-0-X.

This is an interesting book that I enjoyed reading, because unlike $99 \%$ of medical textbooks, the author challenges conventional views and makes the reader think. I am certainly persuaded that the function of the oesophageal muscle has been largely ignored, compared with other components thought to play a part in oesophageal disease and the radiological evidence of longitudinal muscle function, seems quite compelling.

The book is written in dogmatic style, rather like a lawyer making a case for the prosecution. $\mathrm{He}$ chooses to ignore the 'defence' evidence and this is both the strength and weakness of the text. The basis of Dr Stiennon's hypothesis is that the longitudinal muscle of the oesophagus is somehow responsible for just about every benign oesophageal disorder. I suspect that he is right about longitudinal muscle function and the subsequent effects of oesophageal shortening. Everything seems fine until the 'lawyer' has to sum up for the jury at the end of each chapter. It is here that the author strays from the evidence and in particular that which does not fit with his theory. The chapter on Barrett's oesophagus is particularly short sighted and uses the most tenuous literature review to support the author's notion that this is yet another condition explained entirely by longitudinal muscle action and that the Barrett's segment is no more than a cylinder of stomach, pulled up by the longitudinal muscle of the oesophagus.

While I agree with the author's scepticism regarding current theories of the pathogenesis of achalasia, I find them no more bizarre than his interpretation that diffuse oesophageal spasm and achalasia are manifestations of undiagnosed obstruction due to incarceration of the gastric fundus. I would be interested to know how patients with diffuse oesophageal spasm get their symptoms at night, when motor function is largely quiescent. It is when the author strays into the field of surgery, that he really gets my back up. Most of his comments about anti-reflux surgery and surgery for achalasia, are so misplaced that one wonders if he has ever read any of the surgical literature on the oesophagus in the past 40 years! There is no shortage of literature for instance, testifying to the poor performance of the Allison repair in the long term and by $\mathrm{Dr}$ Stiennon's theories, all Nissen fundoplications should result in gasbloat syndrome. No explanation is offered why over $95 \%$ of these operations do not produce the syndrome.

This book should be read by 'oesophagologists', if only to challenge their existing views. I cannot recommend it, however, to a wider audience as a balanced account of the role of the longitudinal muscle in the pathogenesis of oesophageal disease. The author claims that many of our beliefs about oesophageal function and disease, stem from preconceived notions. He uses the analogy of 'The Flat Earth Society' to condemn these views as two dimensional in a three dimensional organ. I would remind readers, however, of $\mathrm{T} \mathrm{H}$ Huxley's aphorism, that 'The great tragedy of science is the slaying of a beautiful hypothesis by an ugly fact'. At the moment, there are too many ugly facts to support Dr Stiennon's hypothesis.

D A ALDERSON

NOTES

\section{Digestive endotherapy}

The XIVth European Workshop on Digestive Endotherapy will be held on 18-20 June, 1996 in Brussels. Further information from: Administrative Secretariat, Conference Services sa, Avenue de l'Observatoire, 3, Box
17, B-1180 Brussels, Belgium. Tel: (32) 2 37516 48; fax: (32) 23753299 .

\section{Abdominal imaging}

A course on Abdominal Imaging will be held on 1-5 July 1996 in Wyoming, USA. Further information from: Janice Ford Benner, University of Pennsylvania Medical Center, 3400 Spruce Street, 1 Silverstein Building, Philadelphia, PA 19104, USA. Tel: (215) 662-6904; fax: (215) 349-5925.

\section{Gastrointestinal pharmacology}

A meeting sponsored by the Gastrointestinal (GI) Pharmacology Section of IUPHAR (International Union of Pharmacology) will be held 3-7 September 1996 in Sperlonga, Italy. The meeting is entitled New Approaches to Pharmacotherapy for Gastrointestinal Ulcerative and Inflammatory Disorders. Further information from: Dr Antonio Guglietta, Parke-Davis Research, 2800 Plymouth Road, Ann Arbor, MI, 48105, USA. Tel: (313)-996-2911; fax: (313)-996-4333; e-mail: gugliea@aa.wl.com.

\section{Clinical nutrition}

The Leeds Course in Clinical Nutrition will be held on 3-6 September 1996. Further details from: Mrs Hilary L Thackray, Department of Continuing Professional Education, Continuing Education Building, Springfield Mount, Leeds LS2 9NG. Tel: 0113233 3233; fax: 01132333240 .

\section{Inflammatory bowel disease}

An International Meeting on Inflammatory Bowel Disease will be held in Capri, Italy, on 19-21 September 1996. Further information from: Professor Renzo Caprilli, Cattedra di Gastroenerologia, Università de L'Aquila, Via S Sisto 22E 67100 L'Aquila, Italy. Tel: 39 862 433407; fax: 39862433383.

\section{CORRECTION}

$$
-
$$

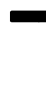

\section{Correction}

An authors' error occurred in the paper by $\mathrm{Dr}$ R J Scott and others (Gut 1995; 36: 731-6). The mutation described at nucleotide 5934 , codon 1978 should be nucleotide 5960, codon 1987 causing a stop codon 61 codons later as shown in the accompanying Figure.

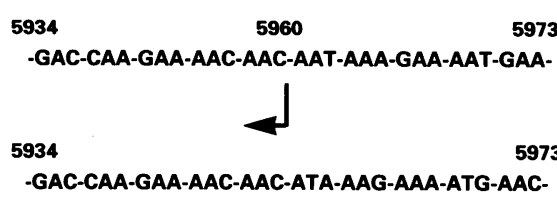

Figure 3: Sequence analysis of exon $15 n$ showed a base pair deletion at position 5960, which was identified in patients who presented with colonic disease alone or extracolonic disease with or without colonic disease. 